\begin{tabular}{|c|c|c|c|c|c|c|c|c|}
\hline \multicolumn{3}{|c|}{$\begin{array}{l}\text { 2. To: (Receiving Organization) } \\
\text { Distribution }\end{array}$} & \multicolumn{2}{|c|}{$\begin{array}{l}\text { 3. From: (Originating Organization) } \\
\text { SNF Project }\end{array}$} & \multicolumn{4}{|c|}{$\begin{array}{r}\text { 4. Related EDT No.: } \\
\text { N/A }\end{array}$} \\
\hline \multicolumn{3}{|c|}{ 5. Proj./Prog./Dept./Div.: } & \multicolumn{2}{|c|}{$\begin{array}{l}\text { 6. Design Authority/ Design Agent/Cog. } \\
\text { Engr.: }\end{array}$} & \multicolumn{4}{|c|}{ 7. Purchase Order No.: } \\
\hline \multirow{2}{*}{\multicolumn{5}{|c|}{$\begin{array}{l}\text { 8. Originator Remarks: } \\
\text { N/A }\end{array}$}} & \multicolumn{4}{|c|}{$\begin{array}{l}\text { 9. Equip./Component No.: } \\
\text { N/A }\end{array}$} \\
\hline & & & & & \multicolumn{4}{|c|}{$\begin{array}{l}\text { 10. System/Bldg./Facility: } \\
\text { Spent Nuclear Facility }\end{array}$} \\
\hline \multirow{3}{*}{\multicolumn{5}{|c|}{ 11A. Design Baseline Document }} & \multicolumn{4}{|c|}{$\begin{array}{c}\text { 12. Major Assm. Dwg. No.: } \\
\text { N/A }\end{array}$} \\
\hline & & & & & \multicolumn{4}{|c|}{$\begin{array}{l}\text { 13. Permit/Permit Application No.: } \\
\text { N/A }\end{array}$} \\
\hline & & & & & \multicolumn{4}{|c|}{$\begin{array}{l}\text { 14. Required Response Date: } \\
\text { N/A }\end{array}$} \\
\hline \multicolumn{2}{|l|}{15.} & \multicolumn{3}{|c|}{ DATA TRANSMITTED } & (F) & (G) & (H) & (I) \\
\hline $\begin{array}{l}\text { (A) } \\
\text { Item } \\
\text { No. }\end{array}$ & (B) Document/Drawing No. & $\begin{array}{l}\text { (C) } \\
\text { Sheet } \\
\text { No. }\end{array}$ & $\begin{array}{l}\text { (D) } \\
\text { Rev. } \\
\text { No. }\end{array}$ & $\begin{array}{l}\text { (E) Titte or Description of Data } \\
\text { Transmitted }\end{array}$ & $\begin{array}{l}\text { Approval } \\
\text { Desig- } \\
\text { Nator }\end{array}$ & $\begin{array}{l}\text { Reasor } \\
\text { for } \\
\text { Trans- } \\
\text { mittal }\end{array}$ & $\begin{array}{c}\text { Origi- } \\
\text { nator } \\
\text { Dispo- } \\
\text { sition }\end{array}$ & $\begin{array}{l}\text { Receiv- } \\
\text { er } \\
\text { Dispo- } \\
\text { sition }\end{array}$ \\
\hline 1 & SNF-3930 & & 0 & $\begin{array}{l}\text { Krohne Flow Indicator/Alarm - Local } \\
\text { Helium Flow Indication and High Flow } \\
\text { Alarm in the SCHe Purge System }\end{array}$ & $Q$ & 2 & 1 & $\mathrm{~N} / \mathrm{A}$ \\
\hline & & & & & & & & \\
\hline & & & & & & & & \\
\hline & & & & & & & & \\
\hline & & & & & & & & \\
\hline
\end{tabular}

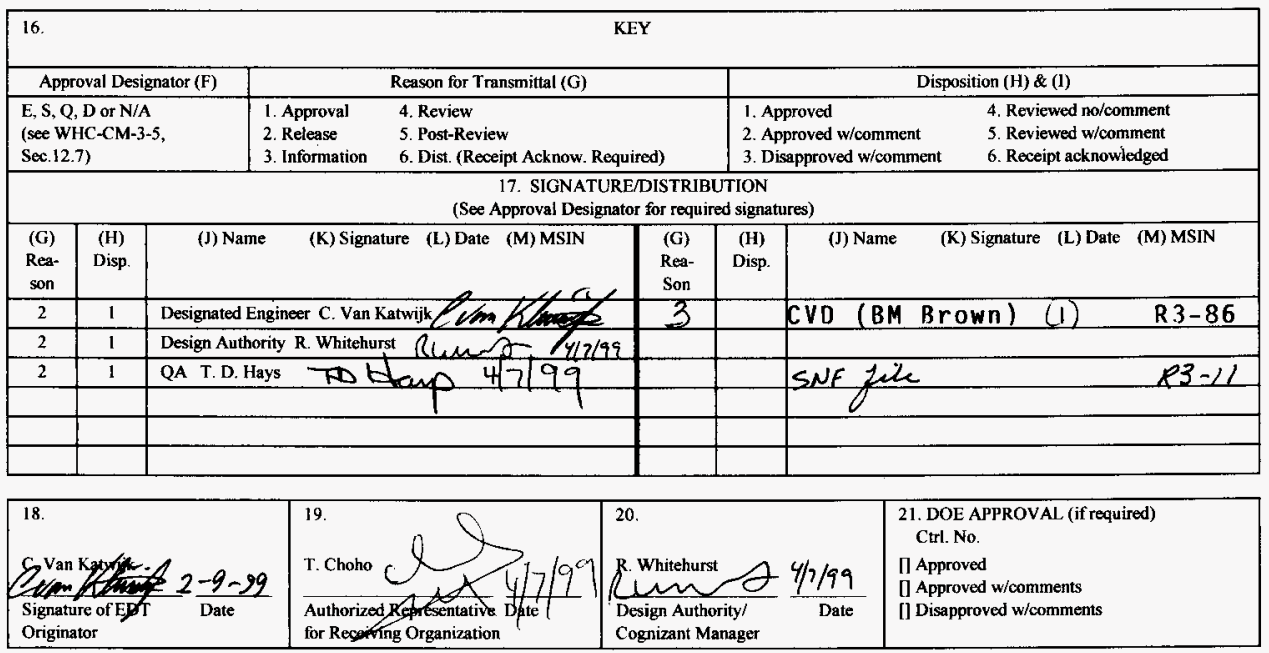




\section{Krohne Flow Indicator/Alarm - Local Helium Flow Indication and High Flow Alarm in the SCHe Purge System}

Carl Van Katwijk

Numatec Hanford Co, Richland, WA 99352

U.S. Department of Energy Contract DE-AC06-96RL13200

EDT/ECN: 626279

UC: 620

Org Code: $2 \mathrm{G} 300$

Charge Code: 105559/A000

B\&R Code: $39 \mathrm{EW} 40400$

Total Pages: 13

Key Words: Flow indicator - Alarms

Abstract: Krohne Flow Indicator/Alarm - Local Helium Flow Indication and High Flow Alarm in the SCHe Purge System

CGI-SNF-D-13-P5-034

TRADEMARK DISCLAIMER. Reference herein to any specific commercial product, process, or service by trade name, trademark, manufacturer, or otherwise, does not necessarily constitute or imply its endorsement, recommendation, or favoring by the United States Government or any agency thereof or its contractors or subcontractors.

Printed in the United States of America. To obtain copies of this document, contact: Document Control Services, P.0. Box 950, Mailstop H6-08, Richland WA 99352, Phone (509) 372-2420; Fax (509) 376-4989.

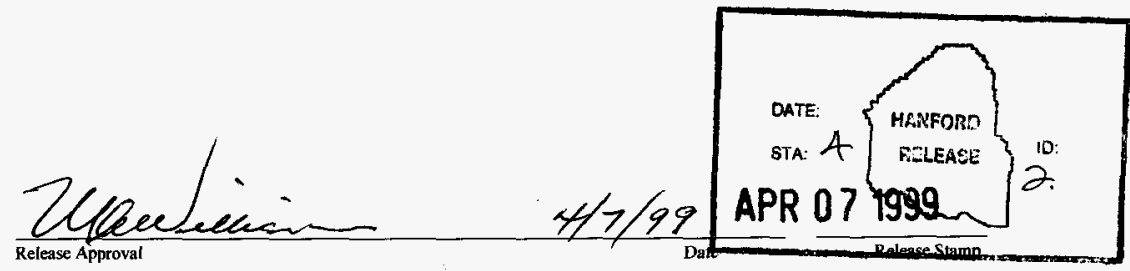

Approved for Public Release 
Commercial Grade Item Upgrade Dedication Form

ECN No. NA CGI No. CGL-SNF-D-13-P5-034
Title: KROHNE FLOW INDICATOR/ALARM - LOCAL HELIUM FLOW
INDICATION AND HIGH FLOW ALARM IN THE SCHE PURGE
SYSTEM

Rev. No. 0 SNF - 3930

Page 1 of 12

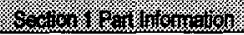

\begin{tabular}{|c|c|c|c|}
\hline Item No.: NA & Manufacturer. & & Supplier: \\
\hline Mfg. PartModel No.: & & Supplier's PN: & \\
\hline
\end{tabular}

Part Description:

End Use Description:

\begin{tabular}{|c|c|c|c|}
\hline \multicolumn{4}{|c|}{ S. } \\
\hline $\begin{array}{l}\text { Equipment No.: SCHe- } \\
\text { FI/FSH-5*10, 5*29, } \\
5 * 49,5 * 52,5 * 69, \\
5 * 72,5 * 76,5 * 77, \\
5 * 78,5 * 79\end{array}$ & $\begin{array}{l}\text { Specification No.: W-441. } \\
\text { P5, Rov, } 2\end{array}$ & Manufacturer. Krohne & Past P.O. No.: NA \\
\hline $\begin{array}{l}\text { Manufacturer's Part/Model } \\
\text { No.: DK } 37 / M \text { R K125 } \\
\text { W/120 VAC RELAY } \\
\text { AND W/O NEEDLE } \\
\text { VALVE }\end{array}$ & \multicolumn{2}{|c|}{ Equipment Supplier (ff dfferent from manufacturer): TBD } & $\begin{array}{l}\text { Equip. Supplier's Part No: } \\
\text { NA }\end{array}$ \\
\hline
\end{tabular}

Component Description: These flow Indicators/alarms are located in the 15 psig section of the SCHe supply lines after the 15 psig pressure reducing valves and before the second pressure reducing valves set to 7 and to 2 psig. The flow indicetors monitor the flow going to the SCHe purge lines.

This design is used for each of the SCHe supply lines (4). The switch/alarm is safety class GS.

1. Is the Item available from a catalog from a qualified NQA1 or 609000 supplier (coordinate with project CGI interface Engineer or BTR)?

[ ] YES (go to \#2 below)

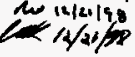

[X] NO (go to procedure step 5.3.2, proceed to decicale item.)

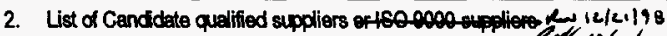
company name and type contact name $C / K / 2 / 2 / / 2 p$ phone NA

3. Recommended Procurement Strategy (coordinate with project CGI interface Engineer or BTR):

NA

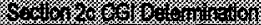

1. Question \#1: is the Item subject to design or specification requirements that are unique to nuclear facilities or activities?

[ ] YES (the Item is not commercial grade)

[X] NO (continue) 
Commercial Grade Item Upgrade Dedication Form

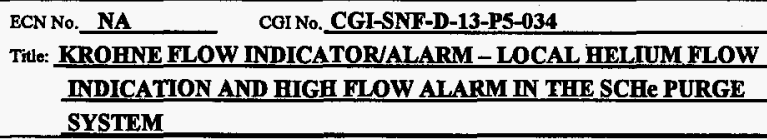

2. Question \#2: Is the Item used in applications other than nuclear facilities or activities?

I ] NO (the item is not commercial grade)

[X] YES (continue)

3. Question \#3: Is the Item ordered from manufacturer/supplier on the basis or specifications set forth in the manufacturers catalog?

I I NO (the Item is not commercial grade)

[X] YES (continue)

[X] All three criteria have been satisfied. The ltem meets the definltion of commercial grade.

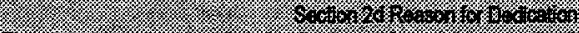

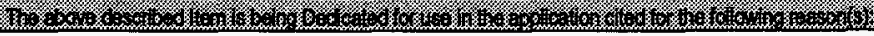

[X] liem is being purchased from a non ESL manufacturer supplier as commercial grade to be used in a Safely Class application.

[ I Item is being purchased from a non ESL manufacturer supplier as commercial grade to be used in a Safety Significant application.

I I Item was punchased from a non ESL manufacturer supplier as commercial grade to be used in a Safety Class application.

I I Item was purchased from a non ESL manufacturer supplier as commercial grade to be used in a Safely Significant application.

1 ] Other ('like-for-like', similar, substitution, replacement evaluation)

\section{A. Part/Component Safety Function:}

1. Pressure Boundery Integrity- Prevents helium leakage from the SCHa System.

\section{Maintain pressure boundary after Seismic ovent.}

3.

B. Part/Component Functional Mode

Salety Function \#1:

[ ] Active - Mechanical or Electrical change of state is required to occur for the component to perform its safety function

[X] Passive - Change of state is not required for the component to perform its safely function Safety Function \#2:

[ ] Active - Mechanical or Electrical change of state is required to cocur for the component to perform its safety function.

[X] Passive - Change of state is not required for the component to perform its satety function Safety Function \#3:

[ ] Active - Mechanical or Electrical change of state is required to occur for the component to perform its safety function.

I 1 Passive - Change of state is not required for the component to perform its safety function 
Commercial Grade Item Upgrade Dedication Form

ECN No. NA CGI No. CGI-SNF-D-13-P5-034

Title: KROHNE FLOW INDICATOR/ALARM - LOCAL HELIUM FLOW INDICATION AND HIGH FLOW ALARM IN THE SCHE PURGE SYSTEM

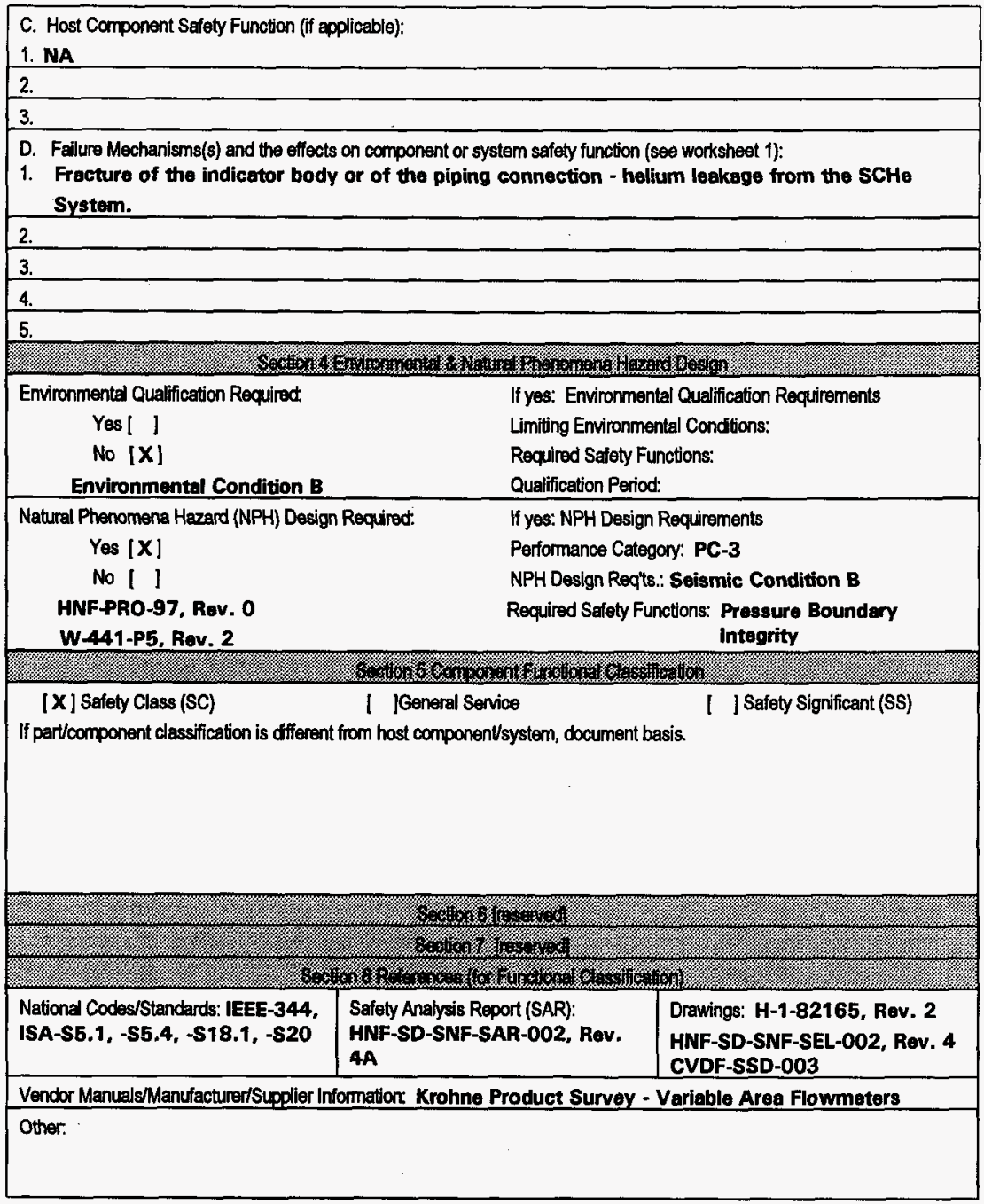


Title: KROHNE FLOW INDICATOR/ALARM - LOCAL HELIUM WLOW INDICATION AND HIGH FLOW ALARM IN THE SCHE PURGE SYSTEM

\begin{tabular}{|c|c|c|c|c|}
\hline 3. & \multicolumn{4}{|l|}{ 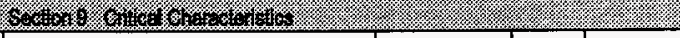 } \\
\hline $\begin{array}{l}\quad \text { Critical Characteristics } \\
\text { Verification Document: Vendor } \\
\text { Specifications, } \\
\text { HNF-SD-SNF-SEL-002, Rev. } 4\end{array}$ & Acceptance Criteria/Tolerances & $\begin{array}{l}\text { Acceptance } \\
\text { Method }\end{array}$ & ID & Function \\
\hline \multicolumn{5}{|c|}{ 1. Item Identification Critical Characteristics (necessary for reasonable assurance that the Item delivered is the Item specified) } \\
\hline Nameplate Data & Per Vendor Manuel & $1, \mathrm{IN}$ & $\mathbf{x}$ & \\
\hline Model Number & $\begin{array}{l}\text { DK 37/M R K125 W/120 VAC } \\
\text { Relay and W/O Needie Valve }\end{array}$ & $1, \mathrm{IN}$ & $\mathbf{x}$ & \\
\hline Manufacturer & Krohne & $1, \mathrm{IN}$ & $\mathbf{x}$ & \\
\hline Process Connection & $\begin{array}{l}1 / 4 \text { Inch FNPT (Horizontal } \\
\text { Connections) }\end{array}$ & $1 . \mathrm{IN}$ & $\mathbf{x}$ & \\
\hline Indicator Range & $\begin{array}{l}0.32--3.2 \text { SCFM for FI-5*10, } \\
5 * 29,5 * 49,5 * 69 . \\
0.30--3.0 \text { SCFM for FI-5*76, } \\
5 * 77,5 * 78,5 * 79 \\
\end{array}$ & $1, \mathrm{IN}$ & $\mathbf{x}$ & \\
\hline \multicolumn{5}{|c|}{ 2. Physical Critical Characteristics (necessary for reasonable assurance that the ltem delivered is the litem specified) } \\
\hline Material, Body & Stainless Steel & $1, T$ & $\mathbf{x}$ & \\
\hline Material, Process Connection & Stainless Stoel & $1, T$ & $\mathbf{x}$ & \\
\hline \multicolumn{5}{|c|}{$\begin{array}{l}\text { 3. Performance Critical Characteristics (necessary \& sufficient for reasonable assurance that the ltem will perform its intended } \\
\text { safety function(s)) }\end{array}$} \\
\hline Pressure Boundery Integrity & $\begin{array}{l}\text { No Leakage at Test Pressure of } \\
165 \text { Psig. Note } 3 .\end{array}$ & $1, T$ & & $\mathbf{x}$ \\
\hline Environmental & Note 1 & & & \\
\hline Seismic Condition B & Note 2 & $1, T$ & & $\mathbf{x}$ \\
\hline \multicolumn{2}{|c|}{$\begin{array}{l}\text { 4. Notes and Legend } \\
\text { 1. The flow indicator is not subject to degradation at ambient } \\
\text { conditions of } 40^{\circ} \mathrm{F} \text { and } 60 \% \text { RH or } 115^{\circ} \mathrm{F} \text { and } 22 \% \text { RH and } \\
\text { is suitable for Environmental Condition B application. } \\
\text { 2. Maintain pressure boundary after Seismic event. } \\
\text { W-441-P5, Rev. } 2 \text {, Appendix } \mathrm{I} \text {, page I-2, provides a seismic } \\
\text { testing plan for these components at a seismic spectra } \\
\text { TBD. } \\
\text { 3. Pressure test at } 110 \% \text { of system design pressure of } 150 \\
\text { psig. Exposure to test pressure may seriously degrade } \\
\text { the readout function. This test is considerad to be a } \\
\text { destructive test. }\end{array}$} & \multicolumn{3}{|c|}{$\begin{array}{l}\text { Acceptance Method } \\
\text { 1. Special Test and Inspection } \\
\text { 1,IN for Inspection } \\
\text { 1,T for Test } \\
\text { 2. Commercial Grade Survey } \\
\text { 3. Source Verification } \\
\text { 4. Vendor/ltem History }\end{array}$} \\
\hline
\end{tabular}


Commercial Grade Item Upgrade Dedication Form ECN No._NA CGINo.CGI-SNF-D-13-P5-034 Rev. No. 0 SNF. 3930

Titie: KROHNE FLOW INDICATOR/ALARM - LOCAL HELTUM FLOW INDICATION AND HIGH FLOW ALARM IN THE SCHE PURGE SYSTEM

Approvals:

Designated Engineeg $12 / 2 \% / 68$

Design Authority. Ren 1412.198

QA Engineer. To domp $12 / 2 / 198$ 
Commercial Grade Item Upgrade Dedication Form

ECN No. NA CGINo.CGI-SNF-D-13-PS-034

Title: KROHINE FLOW INDICATOR/ALARM - LOCAL HELIUM FLOW INDICATION AND HIGH FLOW ALARM IN THE SCHE PURGE SYSTEM

\begin{tabular}{|c|c|c|}
\hline \multicolumn{3}{|c|}{$\begin{array}{c}\text { WORKSHEET } 1 \\
\text { DETERMINATON OF FALURE MECHANISMSMODES }\end{array}$} \\
\hline (F) & 8 EOThu & 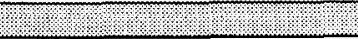 \\
\hline $\begin{array}{l}\text { Typical Failure } \\
\text { Mechanisms }\end{array}$ & Definition & $\begin{array}{l}\text { Applicable to Component } \\
\text { under Evaluation }\end{array}$ \\
\hline Fracture & $\begin{array}{l}\text { Separation of a solid accompanied by little or no } \\
\text { macroscopic plastic deformation. }\end{array}$ & $\begin{array}{l}\text { Yes [X ] No [ ]; If Yes, indicate } \\
\text { failure Mode. Failure of } \\
\text { Transmitter Bodv or the } \\
\text { Process Connection }\end{array}$ \\
\hline Corrosion & \multirow{3}{*}{$\begin{array}{l}\text { The gradual deterioration of a material due to } \\
\text { chemical or electrochemical reactions, such as } \\
\text { oxidation, between the material and its environment. } \\
\text { Destruction of materials by the abrasive action of } \\
\text { moving fluids, usually accelerated by the presence } \\
\text { of solid particles carried with the fluid. } \\
\text { An electrical circuit that is unintentionally broken so } \\
\text { that there is no complete path for current flow. }\end{array}$} & $\begin{array}{l}\text { Yes [ ] No [X]; If Yes, indicate } \\
\text { failure Mode. }\end{array}$ \\
\hline Erasion & & $\begin{array}{l}\text { Yes [ ] No [X]; If Yes, indicate } \\
\text { failure Mode. }\end{array}$ \\
\hline Open Circuit & & $\begin{array}{l}\text { Yes [ ] No [X]; If Yes, indicate } \\
\text { failure Mode. }\end{array}$ \\
\hline Short Circuit & \multirow{3}{*}{$\begin{array}{l}\text { An abnormal connection by which an electrical } \\
\text { current is connected to ground, or to some } \\
\text { conducting body, resulting in excessive current flow. } \\
\text { Clogging of a filtering medium resulting in the } \\
\text { inability to perform its purification function or } \\
\text { blockage of flow. } \\
\text { Binding of a normally moving item through excessive } \\
\text { pressure, temperature, friction, jamming. }\end{array}$} & $\begin{array}{l}\text { Yes [ ] No [X]; If Yes, indicate } \\
\text { failure Mode. }\end{array}$ \\
\hline Blockage & & $\begin{array}{l}\text { Yes [ ] No [X]; If Yes, indicate } \\
\text { failure Mode. }\end{array}$ \\
\hline Seizure & & $\begin{array}{l}\text { Yes [ ] No [X]; If Yes, indicate } \\
\text { failure Mode. }\end{array}$ \\
\hline Unacceptable Vibration & \multirow{3}{*}{$\begin{array}{l}\text { Mechanical oscillations produced are beyond the } \\
\text { defined permissible limits due to unbalancing, poor } \\
\text { support, or rotetion at critical speeds. } \\
\text { A loss of mechanical and physical properties of a } \\
\text { material due to exposure to high temperatures, } \\
\text { radiation exposture. } \\
\text { Under the action of excessive external forces the } \\
\text { material of the part has been deformed or distorted. }\end{array}$} & $\begin{array}{l}\text { Yes [ ] No [X]; If Yes, indicate } \\
\text { failure Mode. }\end{array}$ \\
\hline Loss of Properties & & $\begin{array}{l}\text { Yes [ ] No [X]; if Yes, indicate } \\
\text { failure Mode. }\end{array}$ \\
\hline Excess Strain & & $\begin{array}{l}\text { Yes [ ] No [X]; if Yes, indicate } \\
\text { failure Mode. }\end{array}$ \\
\hline Mechanical Criep & \multirow{2}{*}{$\begin{array}{l}\text { From prolonged exposure to high temperature and } \\
\text { stress, the object will show a slow change in its } \\
\text { physical (shape and dimension) and mechanical } \\
\text { charecteristics. } \\
\text { Fracture characterized by tearing of metal } \\
\text { accompanied by appreciable gross plastic } \\
\text { deformation. }\end{array}$} & $\begin{array}{l}\text { Yes [ ] No [X]; if Yes, indcale } \\
\text { failure Mode. }\end{array}$ \\
\hline Ductile Fracture & & $\begin{array}{l}\text { Yes [ ] No [X]; if Yes, indicate } \\
\text { failure Mode. }\end{array}$ \\
\hline \multicolumn{3}{|c|}{ 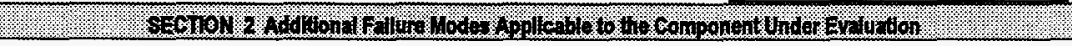 } \\
\hline \multicolumn{3}{|c|}{$\begin{array}{l}\text { 1. Process Connection/Body Break } \\
\text { 2. }\end{array}$} \\
\hline
\end{tabular}


Commercial Grade Item Upgrade Dedication Form

ECN No. NA CGI No. CGI-SNF-D-13-P5-034
Tide: KROMNE FLOW INDICATOR/ALARM-LOCAL HELIUM HLOW
INDICATION AND HIGH FLOW ALARM IN THE SCHE PURGE
SYSTEM

Rev. No. 0 SNF-3930

Page 7 of 12

CHECKLIST 1

ACCEPTANCE METHOD 1

SPECIAL TEST/INSPECTION VERIFICATION

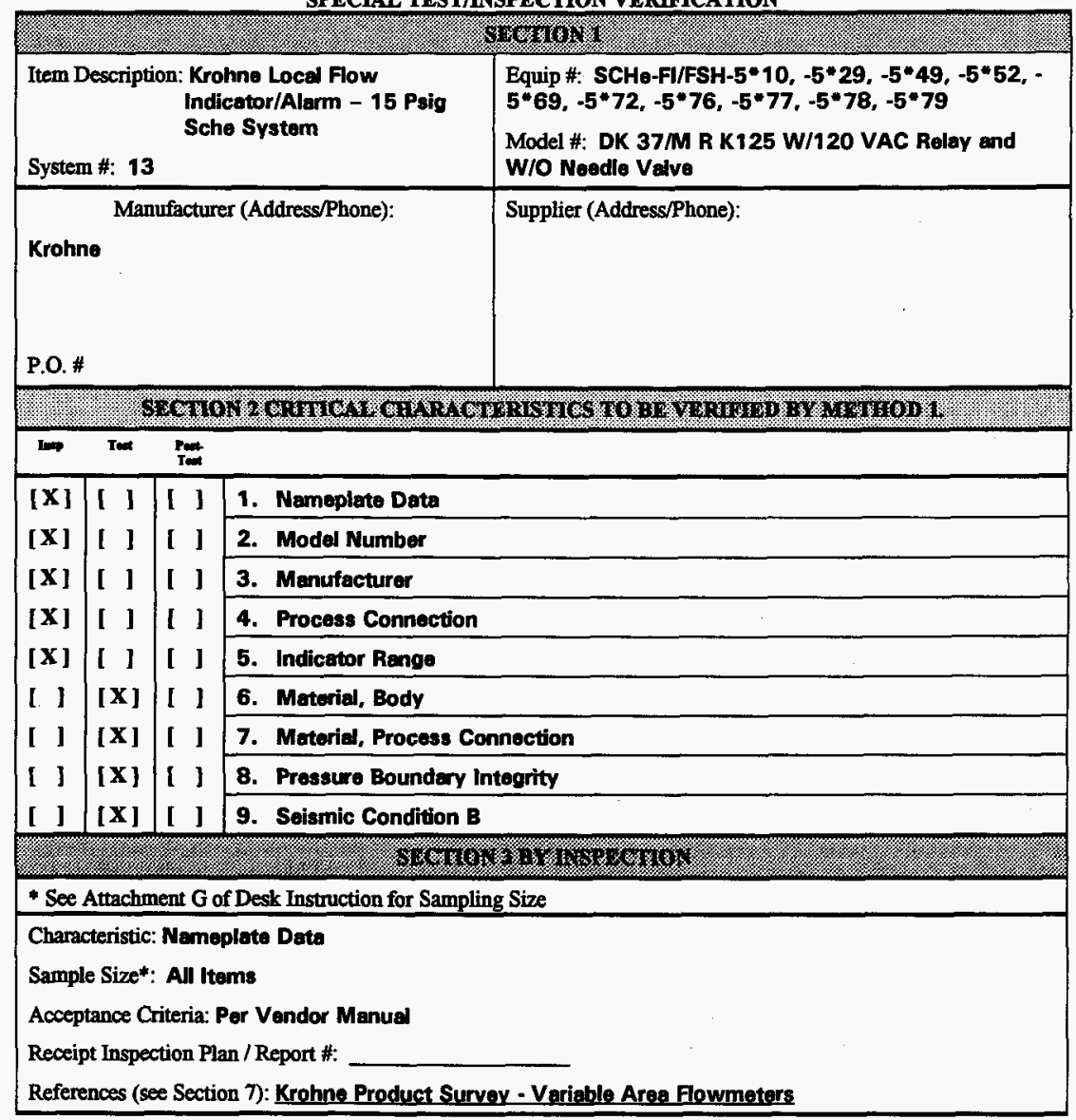


Title: KROHNE FLOW INDICATOR/ALARM - LOCAL HELIUM KLOW INDICATION AND HIGH FLOW ALARM IN THE SCHE PURGE SYSTEM

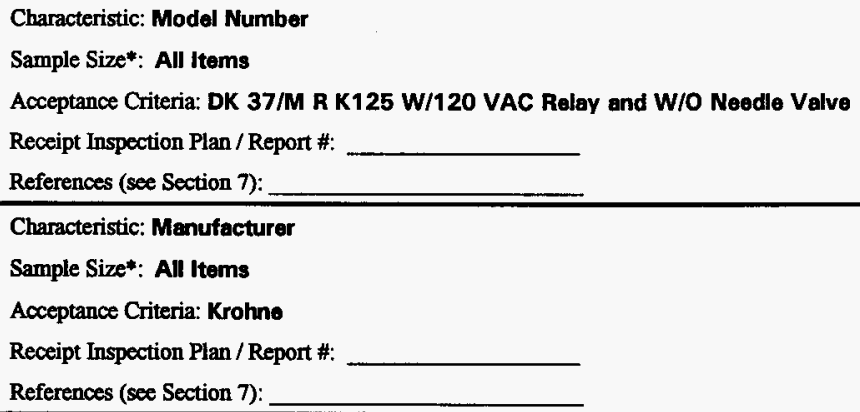

* See Attachment G of Desk Instruction for Sampling Size

Test To Be Performed by:

[ ] Purchaser

[ ] Supplier/Manufacturer**

[ ] Other
Number of Items to be Tested:

Test/nspection Location:

Characteristic for Test: Materiad, Body

Acceptance Criteria: Stainless Steol

Sample Size*: Normal Sampling Sizo

Actual Test Value:

Test Plan and Report \#: References (see Section 7): 
Tïle: KROFNE WLOW INDICATORALARM - LOCAL HELIUM FLOW INDICATION AND HIGR FLOW ALARM IN THE SCHE PURGE SYSTEM

Characteristic for Test: Material, Process Connection

Acceptance Criteria: Stainless Stoel

Sample Size*: Normal Sampling Size

Actual Test Value:

Test Plan and Report \#: References (see Section 7):

Characteristic for Test: Pressure Boundary Integrity

Acceptance Criteria: No Leakage at Test Pressure of 165 Psig

Sample Size*: Normal Sampling Size

Actual Test Value:

Test Plan and Report \#: References (see Section 7):

Characteristic for Test: Seismic Condition B

Acceptance Criteria: Meintain Pressure Boundary After Seismic Event. W-441-P5, Rev. 2, Appendix I, page 1-2, provides a seismic testing plan for these components at a seismic spectra TBD.

Sample Size*: Normal Sampling Size

Actual Test Value:

Test Plan and Report \#: References (see Section 7):

*"If Supplier/Manufacturer or Other, Refer to CGI Checklist-2 for Support Information 


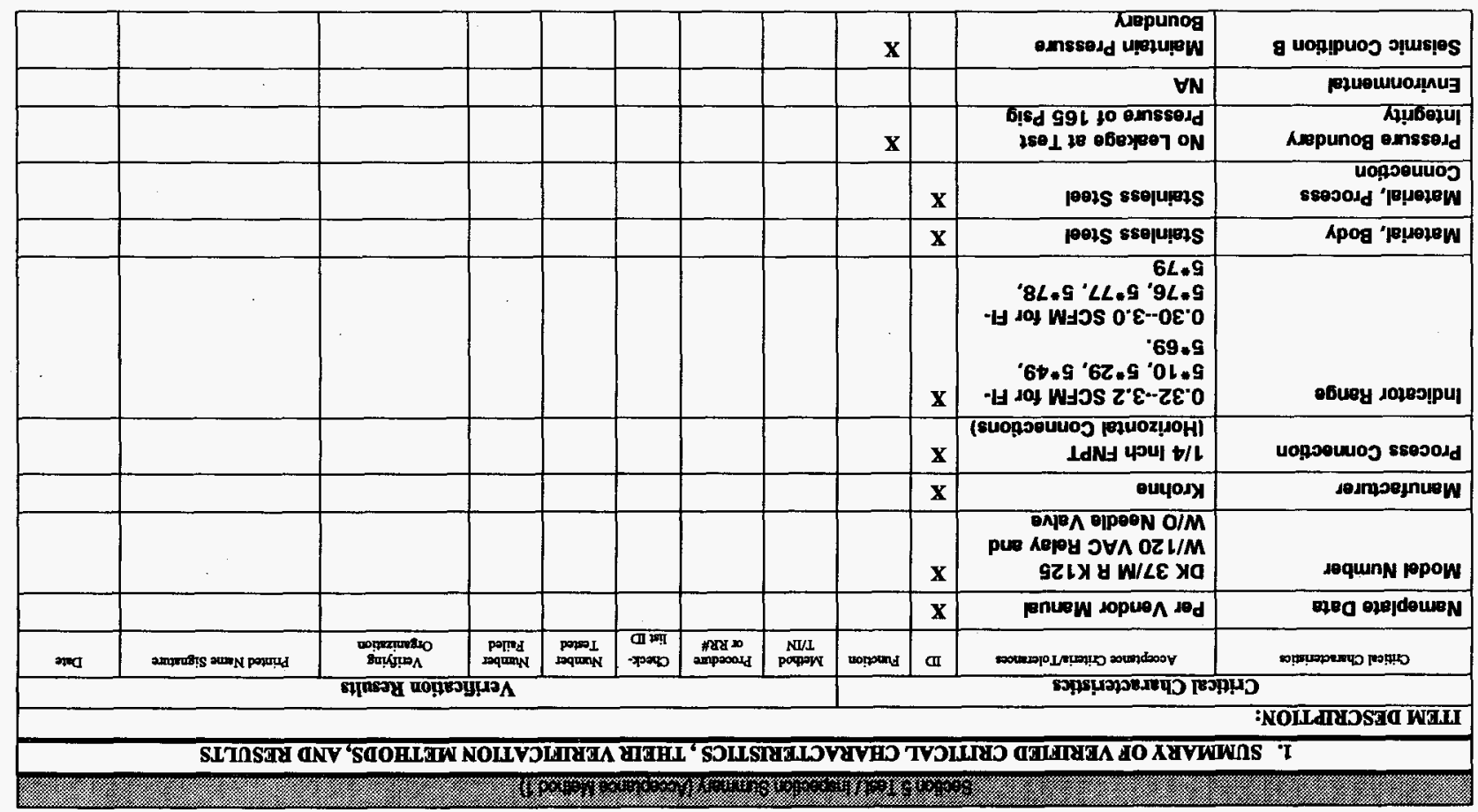

\begin{tabular}{|c|c|}
\hline & 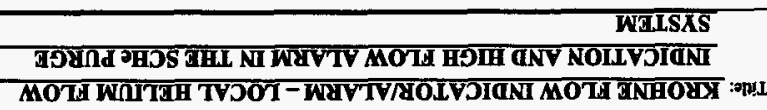 \\
\hline 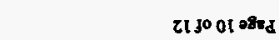 & 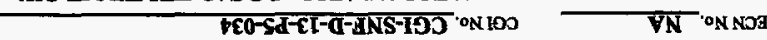 \\
\hline OEbE-INS $\quad$ ON Ard & 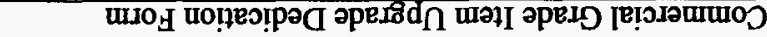 \\
\hline
\end{tabular}


Commercial Grade Item Upgrade Dedication Form

ECN No. NA CGI No.CGI-SNF-D-13-P5-034

Rev. No. 0 SNF-3930

Title: KROHNE FLOW INDICATOR/ALARM - LOCAL FELIUM FLOW INDICATION AND HIGH FLOW ALARM IN THE SCHE PURGE SYSTEM

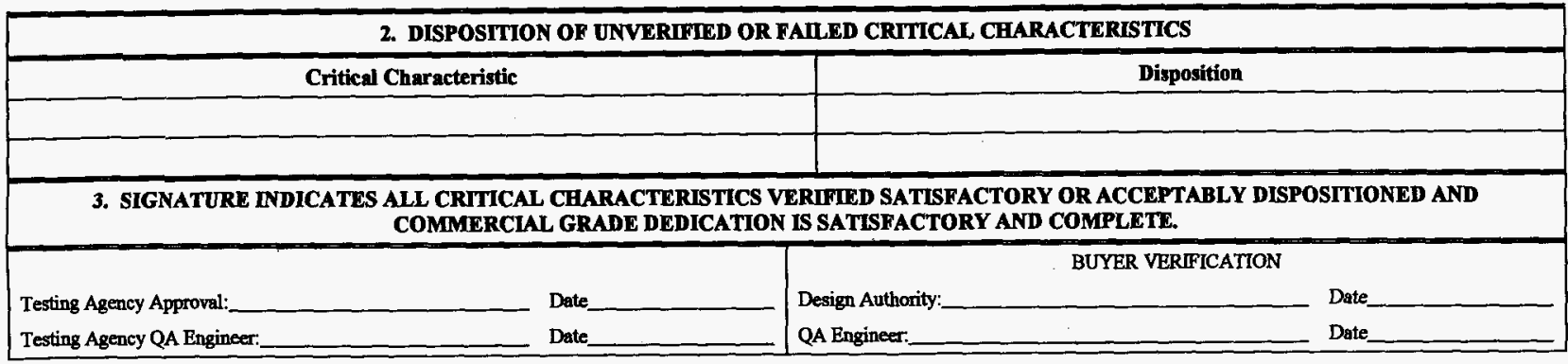


Commercial Grade Item Upgrade Dedication Form ECN No. NA CGI No.CGI-SNF-D-13-P5-034

Title: KROFNE WLOW INDICATOR/ALARM-LOCAL HELIUM FLOW INDICATION AND HIGH FLOW ALARM IN THE SCHE PURGE SYSTEM

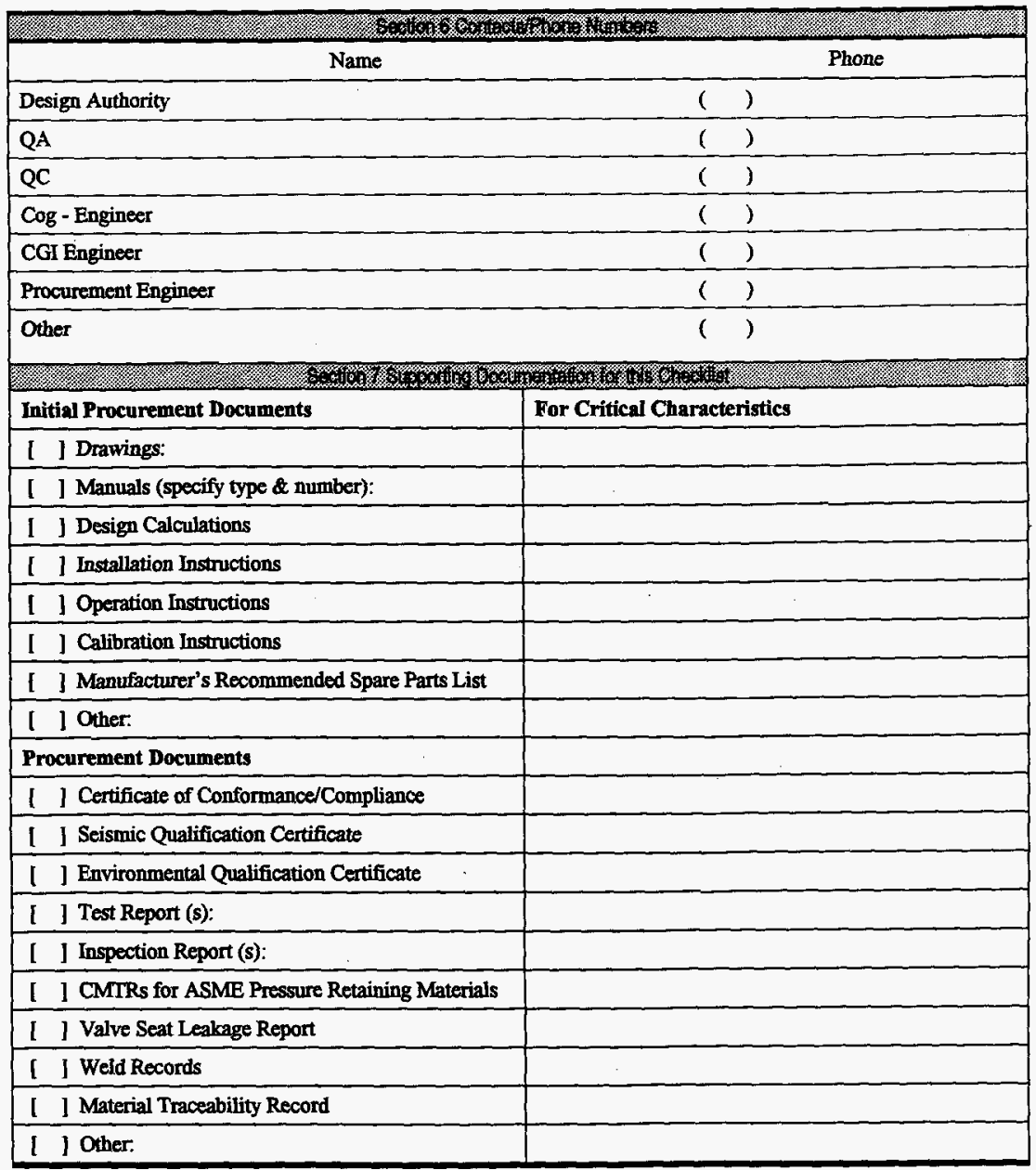

